\title{
A PTILIID BEETLE FROM BALTIC AMBER IN THE MUSEUM OF COMPARATIVE ZOOLOGY
}

\author{
By C. T. Parsons \\ Biological Laboratories, Harvard University
}

In so far as no fossil Ptiliidae have as yet been given names, it may be of interest to describe a species of Ptinella from the Oligocene amber of East Prussia.

Helm, 1896, merely mentions the occurence of the family in Baltic amber, and Klebs, 1911, states on the authority of Edmund Reitter that there is in his collection a Ptenidium and a new genus.

Today the genus Ptinella has a remarkable range. The twenty known species are distributed as follows: Europe (7, 2 of which also occur in the Canary Islands), Japan (1), Honolulu (1), New Zealand (1), North America (2), Central America (3), South America (2), St. Helena Island (1), and the Seychelles Islands (2). Since such a distribution indicates an ancient history, it is not surprising to find the genus in the Oligocene. Moreover, the living forms most commonly occur under the bark of Betula, Quercus, and particularly Pinus, all of which were common in northern Europe in the Oligocene.

\section{Ptinella oligocœnica $n$. sp.}

Fig. 1, a-e

The characters of generic importance are brought together in one paragraph. Body elongate; antennæ 11jointed, long and slender, with long setæ, club elongate; head prominent, rather large; eyes moderate; thorax rather small, transverse, and constricted near the base; scutellum large, triangular; elytra abbreviated, with apices separately rounded; venter of six segments, with apical segment simple; legs rather long and robust, posterior coxæ remote 
and apparently laminate, tarsi 3-jointed, with the apical joint very long and slender, claws long.

The body apparently corneous, somewhat depressed; head and antennæ as figured; outline of pronotum as figured, disc flat, surface sparsely punctate and transversely alutaceous, scutellum coarsely, closely punctate; elytra with discs flattened, humeral angles dentate, coarsely and closely punctate; metasternum sparsely punctate; first ventral segment punctate and as long as the following two combined; ventral segments 2-6 apparently smooth, apical segment with a fringe of hairs; femora and tibiæ covered with setæ; length $.8 \mathrm{~mm}$.
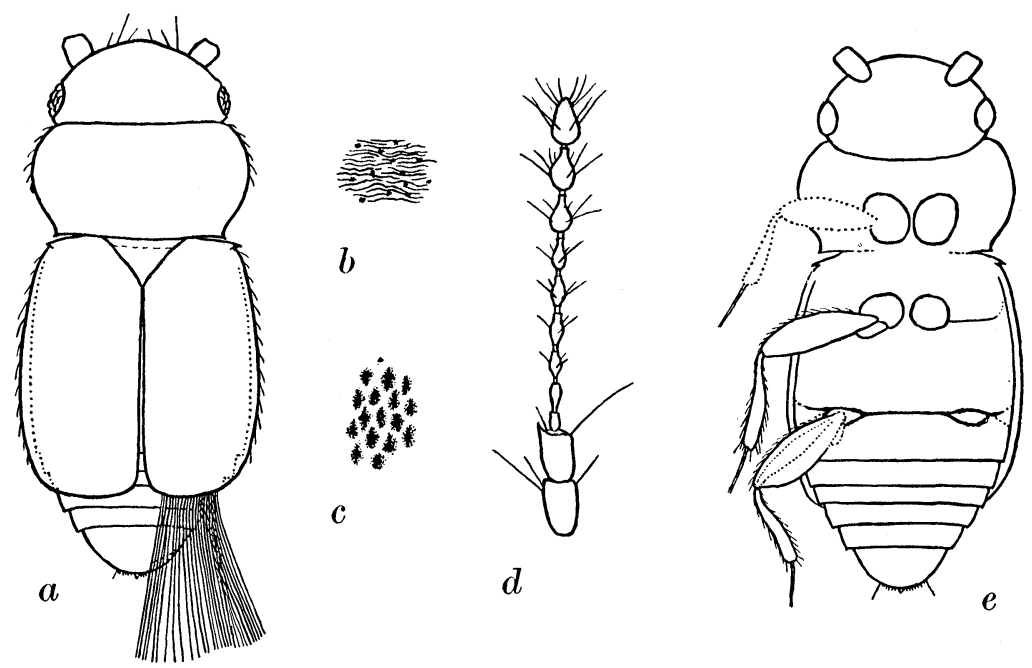

Fig. 1. Holotype of Ptinella oligoconica n. sp. a, dorsal aspect; $b$, surface of pronotum enlarged; $c$, surface of elytron enlarged; $d$, antenna; $e$, ventral aspect.

The above description is from the holotype no. 6839 in the Museum of Comparative Zoology. There is also in the same museum a less satisfactory specimen which is designated paratype no. 6629. Both specimens are part of the W. A. Haren collection.

Because of cloudiness, many important characters of the underside cannot be seen. The one anomalous character 
that can be made out is that the first ventral segment is unusually long. It is interesting that the muscles of the femur, as shown in the drawing of the hind leg, can be clearly seen.

This species differs from the types of $P$. quercus (Lec) and $P$. fungi (Lec.) in being more depressed, corneous, elytra longer, pronotum more transverse. The antennæ are identical with those of $P$. quercus. 

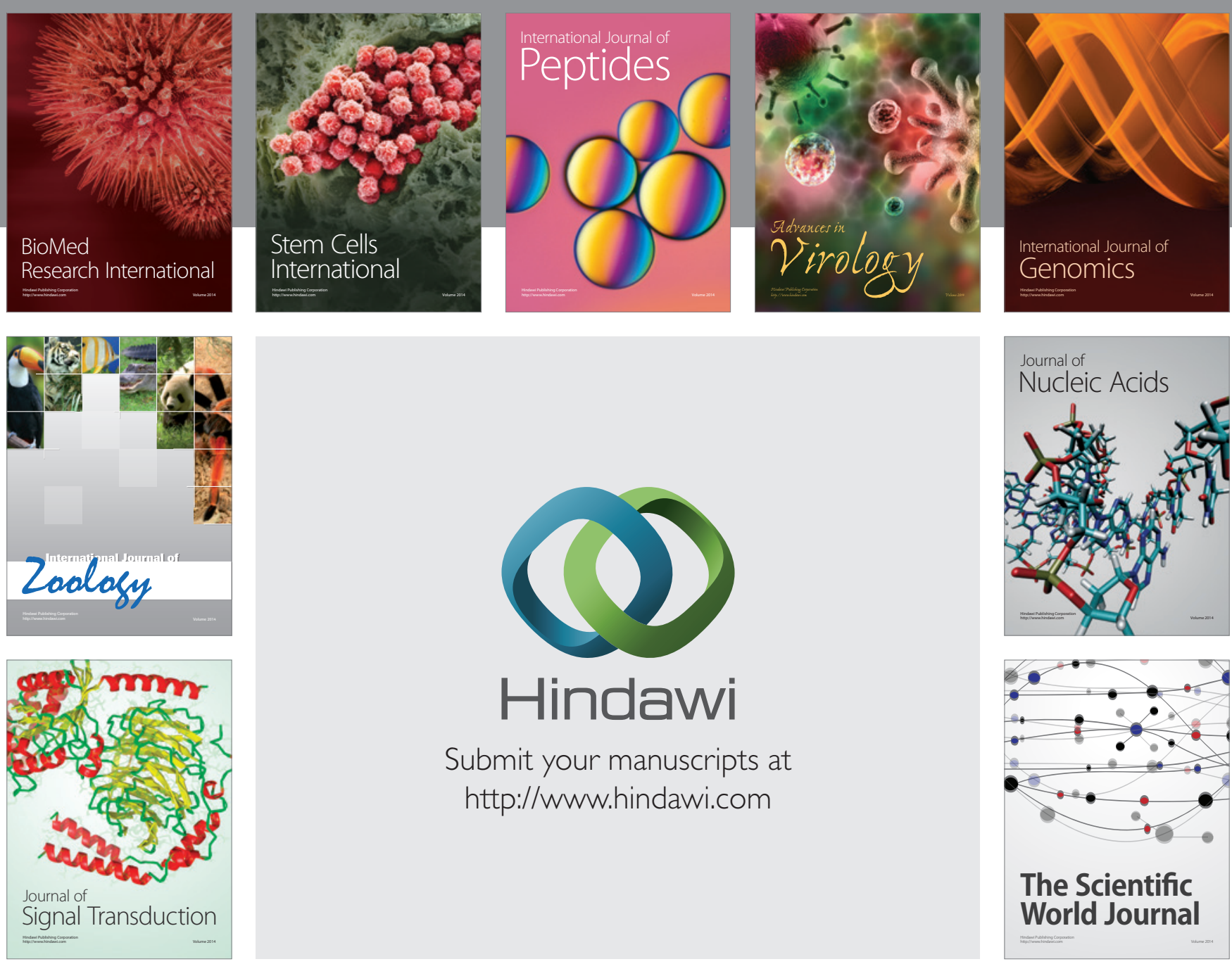

Submit your manuscripts at

http://www.hindawi.com
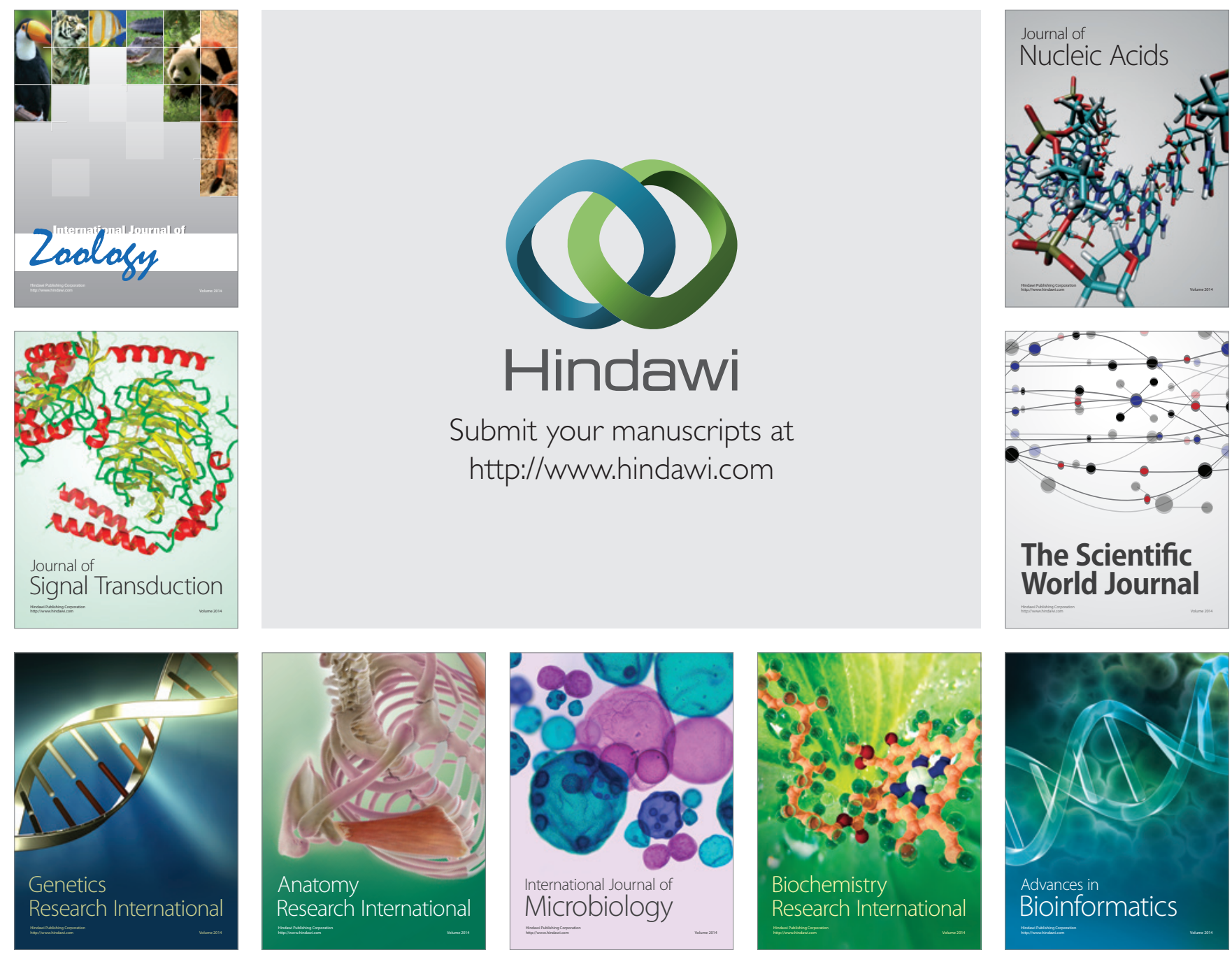

The Scientific World Journal
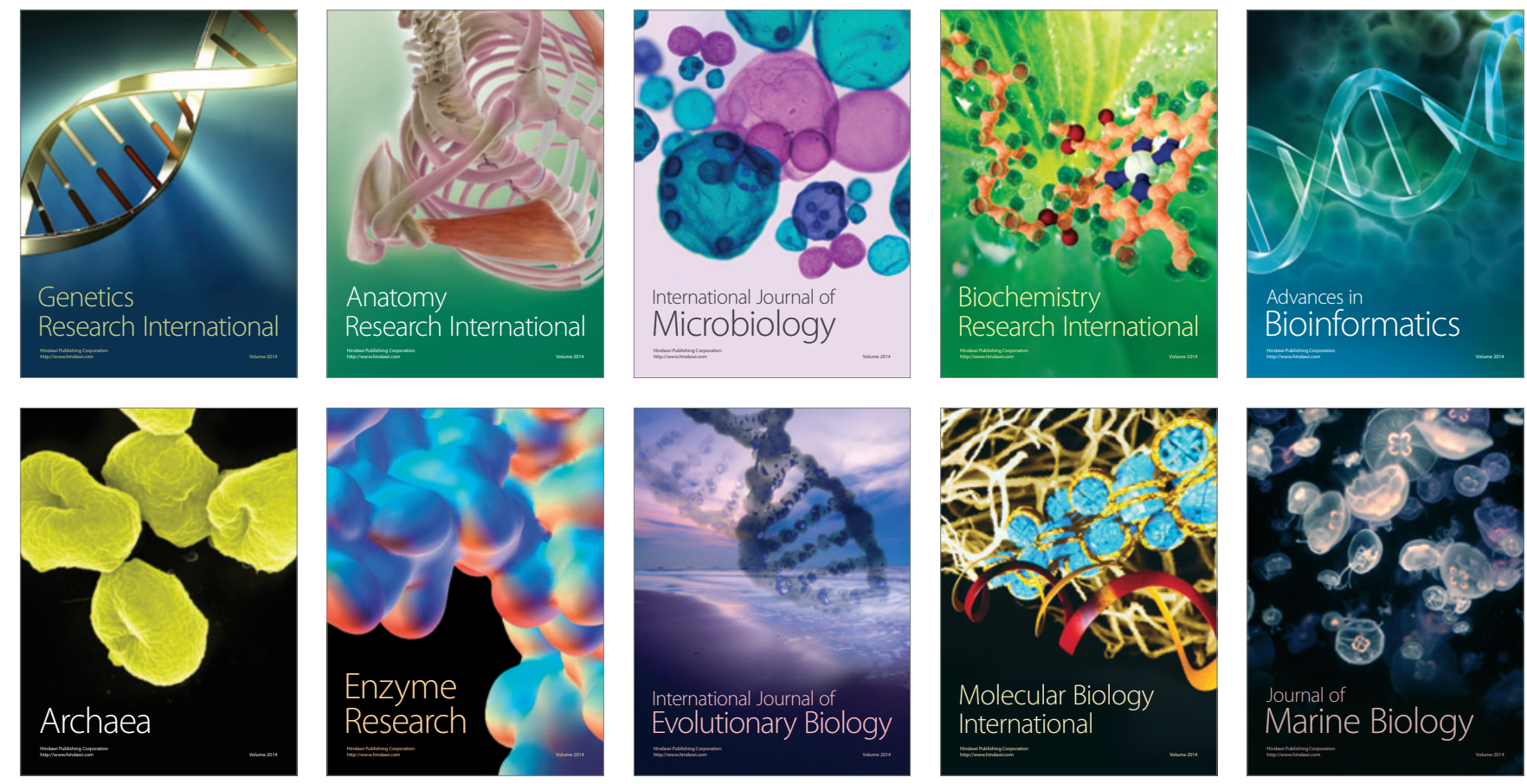